7. Guseva SA, Goncharov YaP, Kurshchuk KV. Recombinant erythropoietin: use in clinic practice. Kyi'v: Logos. 2007:131.

8. Ganz T. Hepcidin, a key regulator of iron metabolism and mediator of anemia of inflammation. Blood. 2003;102:783-8.

9. Gomollon F, Gisbert J. Anemia and inflammatory bowel diseases. World J. Gastroenterol. 2009;15 (37):4659-65.

10. Brasse-Lagnel C, Rarim Z, Letteron P. Intestinal DMT1 cotransporter is down regulated by hepcidin via proteasome internalization and degradation. Gastroenterol. $2011 ; 140(4): 1261-71$.

11. Gasche C, Lomer MC, Cavill I. Iron, anaemia, and inflammatory bowel diseases. Gut. 2004;53(8):1190-7.

12. Milman N. Anemia - still a major health problem in many parts of the world! Ann. Hematol. 2011;90:369-77.

13. Nemeth E, Ganz T. The role of hepcidin in iron metabolism. Acta Hematol. 2009;122(2-3):78-86.

14. Chiang WC, Tsai TJ, Chen YM. Serum soluble transferrin receptor reflects erythropoiesis but not iron availability in erythropoietin-treated chronic hemodialysis patients. Clin. Nephrol. 2002;58:363-9.

15. Skikne BS. Serum transferring receptor. Am. J. Hematol. 2008;83(11):872-5.

16. Stin J, Hartmann F, Dignas AU. Diagnosis and management of iron deficiency anemia in patients with IBD. Nature Revue Gastroent. Hepatol. 2010;7(11):599610.

17. Malope BI, MacPhail AP, Alberts M. The ratio of serum transferring receptor and serum ferritin in the diagnosis of iron status. Br. J. Haematol. 2001;115:84-89.

18. Wish JB. Assessing Iron Status: Beyond Serum Ferritin and Tanserrin Saturation. Clin. J. of the American Cociety of Nephrology. 2006;1(Suppl.1):4-8.

19. World Health Organization. Assessing the iron status of populations. Geneva, WHO 2007.

20. World Health Organization.Worldwide prevalence of anaemia 1993-2005. WHO Global Database on Anaemia. Geneva, WHO 2008.

\title{
I.Л. Височина
}

\section{ОСОБЛИВОСТІ СТАНУ МІСЦВОГО ІМУНІТЕТУ СЛИЗОВИХ ВЕРХНІХ ДИХАЛЬНИХ ШЛЯХІВ У ДІТЕЙ - ВИХОВАНЦІВ ДИТЯЧИХ БУДИНКІВ ТА ЕФЕКТИВНІСТЬ СЕЗОННОї ПРОФІЛАКТИКИ ГРВІ 3 ВИКОРИСТАННЯМ БАГАТОКОМПОНЕНТНОГО РОСЛИННОГО ПРЕПАРАТУ}

Д3 «Дніпропетровська медична академія МОЗ України» кафедра факультетської педіатрії та медичної генетики вул. Дзержинського, 9, Дніпропетровськ, 49600, Україна SE "Dnipropetrovsk medical academy Ministry of Health of Ukraine" Dzerzhinsky Str., 9, Dnipropetrovsk, 49044, Ukraine e-mail:dosia@ua.fm

Ключові слова: діти, дитячі будинки, місцевий імунітет, мікрофлора слизових зіву та носу, сезонна профілактика ГРВI

Key words: children, children's homes, local immunity, mucosal microflora of the nose and throat, seasonal prophylaxis of $A R V I$

Реферат. Особенности состояния местного иммунитета слизистых верхних дыхательных путей у детей воспитаников детских домов и эффективность сезонной профилактики ОРВИ с использованием многокомпонентного растительного препарата. Височина И.Л. Обследовано 116 детей из детских домов в возрасте от 3 до 17 лет в периоде клинического благополучия. Вопрос о возможности проведения иммунологического обследования детей из организованных коллективов и необходимость проведения сезонной профилактики ОРВИ с использованием многокомпонентного растительного препарата были согласованы на уровне городского отдела здравоохранения, городского отдела образования, на уровне директоров детских домов как 
официильных опекунов детей, и полностью соответствовали требованиям биотического комитета с учетом основных положений GCP ICH и Хельсинкской декларачии по биоэтике с учетом прав ребенка. Оченку системы местного иммунитета у всех детей из детских домов проводили неинвазивными методами в периоде клинического благополучия дважды - до начала и после окончания сезонной профилактики ОРВИ. Использовали стандартизированное микробиологическое исследование посевов со слизистых зева и носа; также определялось содержание противомикробных белков лактоферрина (тест-система Human Lactoferrin, Hycult ${ }^{\circledR}$ biotech, НТВ, «БиоХимМак»), а-дефензинов 1-3 (тест-система Human HNP 1-3, Hycult巴 biotech, HTB, «БиоХимМак») с оченкой концентрации SIgA (тест-система «Вектор - БЕСТ», Россия) в секрете ротоглоточной полости у детей детских домов. Показано наличие достоверных изменений системы местного иммунитета слизистых верхних дыхательных путей у часто болеющих ОРВИ детей из организованных коллективов (101 человек) за счет снижения содержания $\alpha$-дефензинов 1-3 и дефицита концентрации секреторного иммуноглобулина А в ротоглоточном секрете, что в 83,3\% наблюдений происходило в сочетании с дисбиозом слизистых зева и носа, влияние состояния которого на местный иммунитет подтверждено проведенным корреляционным анализом. Эффективность применения многокомпонентного растительного препарата в схеме сезонной профилактики ОРВИ у детей составила 88\%, что доказано формированием состояния эубиоза слизистых зева и носа в 78\% наблюдений, в сочетании с достоверным повышением содержания лактоферрина и увеличением конџентрачии SIgA в ротоглоточном секрете у часто болеющих детей из детских домов.

\begin{abstract}
Features of the local immunity state of upper respiratory tract mucosa in children - pupil-orphans of children's home and effectiveness of seasonal prophylaxis of ARVI using multicomponent herbal preparation. Vysochyna I.L. A total of 116 children from children's homes at the age from 3 to 17 years during clinical well-being were inspected. The question on possibility of immunological examination of organized groups of children and the need of seasonal prophylaxis of ARVI using multicomponent herbal preparation hase been submitted with the city department of health, city department of education, with heads of children's homes as official guardians of children, being in full compliance with the requirements of the biotic committee, considering ICH GCP guidelines and Helsinki Declaration on Bioethics, taking into account the rights of a child. The evaluation of the local immunity system in all children from orphanages during clinical well-being by non-invasive methods was done twice - before and after seasonal prophylaxis of ARVI. Standardized microbiological examination of nose and throat mucosa was used; the content of antimicrobial lactoferrin protein (test system Human Lactoferrin, Hycult ${ }^{\circledR}$ biotech, NTV, "BioKhimMak»), $\alpha$-defensins 1-3 (test system Human HNP 1-3, Hycult ${ }^{\circledR}$ biotech, NTV, "BioKhimMak") with assessment of SIgA concentration (test system "Vector - BEST", Russia) in secretion of oropharyngeal cavity was determined. The presence of significant changes in the system of local immunity in the upper respiratory tract mucosa in children (101 humans) with frequent episodes of ARVI due to $\alpha$-defensins 1-3 reduction and deficit of secretory immunoglobulin $A$ concentrations in oropharyngeal secretions was shown. In $83.3 \%$ of cases this occurred in combination with dysbiosis of throat and nasal mucous membranes, the effect of dysbiosis on the local immunity state was confirmed by a correlation analysis. The efficacy of multicomponent herbal preparation in scheme of seasonal ARVI prevention in children was $88 \%$, being proved by the formation of eubiosis of nose and throat mucous membranes in $78 \%$ of cases in combination with a significant increase of lactoferrin content and increase of S IgA concentration in the oropharyngeal secretions in these children.
\end{abstract}

Протягом останніх десятиліть гострі респіраторні вірусні інфекції (ГРВІ) домінують у структурі як інфекційної, так і гострої респіраторної захворюваності населення в Україні, як і в світі, їх актуальність для популяції дітей вихованців дитячих будинків визначається не лише більш високими рівнями як поширеності, так і розповсюдженості ГРВІ порівняно із загальнодержавними статистичними показниками [4, 7], але й особливостями стану біоценозу слизових верхніх дихальних шляхів дітей з організованих колективів $[5,8]$.

Система місцевого імунітету, з точки зору сучасних уявлень, є складовою загальної системи захисту організму, який забезпечує місцеву антимікробну відповідь за рахунок порушення структури або функції кліткової мембрани патогенних мікроорганізмів і може працювати як у комплексі з адаптивною імунною системою, так і самостійно $[1,2,11,12]$.

Ключовими компонентами місцевої системи захисту респіраторного тракту є ендогенні антимікробні пептиди, частина яких синтезуються постійно, інші продукуються у відповідь на інфекцію або запалення $[1,2,11,12]$. Порушення продукції антимікробних пептидів призводить до розвитку імунного дисбалансу й супроводжується порушеннями забезпечення колонізаційної резистентності мікрофлори $[1,2,8]$. У клініці такі феномени реалізуються частими респіраторними захворюваннями та швидким формуванням хронічного запалення на слизових $[5,8,10]$.

Огляд літератури за проблемою показав наявність пріоритетного вибору рослинних 
імунотропних препаратів та адаптогенів у схемах сезонної профілактики ГРВІ у дитячій популяції [10].

Тому метою дійсного дослідження було вивчення особливостей системи місцевого імунітету та мікробіоценозу слизових верхніх дихальних шляхів у дітей 3 дитячих будинків віком від 3 до 17 років у періоді клінічного благополуччя 3 оцінкою клініко-імунологічної ефективності включення багатокомпонентного рослинного препарату в схему сезонної профілактики ГРВІ у цих дітей.

\section{МАТЕРІАЛИ ТА МЕТОДИ ДОСЛІДЖЕНЬ}

Під наглядом перебувало 114 дітей - вихованців дитячих будинків, віком від 3 до 17 років, які проживали у 5 дитячих будинках міського підпорядкування. Питання щодо можливості проведення імунологічного обстеження дітей в організованих колективах та необхідність проведення сезонної профілактики ГРВІ були узгоджені на рівні міського відділу охорони здоров'я, міського відділу освіти, на рівні директорів дитячих будинків як офіційних опікунів, що повністю відповідало вимогам біотичного комітету 3 урахуванням основних положень GCP ICH i Гельсінської декларації з біоетики та 3 урахуванням прав дитини.

У всіх дітей, які були під нашим наглядом, оцінку системи місцевого імунітету проводили неінвазійними методами двічі - до початку та після закінчення сезонної профілактики багатокомпонентним рослинним препаратом. Згідно 3 дизайном, у періоді клінічного благополуччя вивчався біоценоз слизових верхніх дихальних шляхів (стандартизоване мікробіологічне дослідження мазків зі слизових зіву та носу) та визначені концентрації протимікробних білків лактоферрину (тест-система Human Lactoferrin, Hycult $\AA$ biotech, НТВ, «БиоХимМак»), $\alpha$-дефензинів 1-3 (тест-система Human HNP 1-3, Hycult $\mathbb{R}$ biotech, НТВ, «БиоХимМак») 3 оцінкою концентрації SIgA (тест-система «Вектор - БЕСТ», Росія) у секреті ротоглоткової порожнини дітей.

Мазки зі слизових зіву й носу та забір ротоглоткового секрету проводили всім дітям вранці, до ранкового чищення зубів, натще, у присутності медичного працівника та вихователя дитячого будинку з використанням одноразового інструментарію.

Для сезонної профілактики ГРВІ у часто хворіючих дітей віком від 3 до 17 років 3 організованих колективів використовувався рослинний багатокомпонентний препарат 3 імунотропними властивостями у вигляді желе, який є сертифікованим в Україні, має дозвіл Фармкомітету України для його використання в педіатрії 3 метою профілактики частої респіраторної захворюваності. Дозування препарату проводили згідно 3 інструкцією: дітям від 3 до 6 років по 1/2 чайної ложки желе, старшим 6 років - по 1 чайній ложці двічі на день 3 рідиною впродовж чотирьох тижнів [9].

До складу препарату входять екстракти 43 лікарських рослин (250 г желе містить: деревини агаркашт черній (Aqilaria agallocha) - 0.7125 г; квіток надкасхар (Mesua ferrea) -0.285 г; листя тейпатри (Cinnamomum tamala) - 0.285 г; плодів елаічі кхоти (Elettaria cardamomum) - 1.4275 г; плодів пипал бади (Piper longum) - 1.9115 г; кори парул кхал (Stereospermum suaveolens) - 1.855; кори гамбхар кхал (Gmelina arborea) - 0.7125 г; плодів та кори бел кхал (Aegle marmelos) 0.7125 г; кори сона кхал (Oroxylum indicum) 0.7125 г; плодів гокхру кхота (Tribulus terresteris) - 0.7125 г; листя і стебел шалпарани (Desmodium gangeticum) - 0.7125 г; коріння і плодів барахати (Solanum indicum) - 0.7125 г; коріння і плодів канткар (Solanum xanthocarpum) - 0.7125 г; плодів какдасинги (Pistacia integerrima) - 0.7125 г; плодів дракши (Vitis vinifera) - 0.7125 г; плодів харар (кхоти) (Terminalia chebula) - 0.7125 г; стебел грукхи/гилои (Tinospora cordifolia) - 0.7125 г; кореня бала (Sida cordifolia) - 0.7125 г; всієї рослини бхуми амла (Phyllanthus niruri) - 0.7125 г; всієї рослини басака (Adhatoda vasic) - 0.7125 г; всієї рослини дживанти (Leptadenia reticulata) 0.7125 г; кореневищ катхоор (Curcuma zedoaria) 0.7125 г; кореневих бульб нагармотха (Cyperus scariosus) - 0.7125 г; всієї рослини мудг парни (Phaseolus trilobus) - 0.7125 г; всієї рослини маш парни (Termanus labialis) - 0.7125 г; плодів какнаша (Martynia diandra) - 0.7125 г; кореня пунарнава (Boerhaavia diffusa) - 0.7125 г; олії сандалового дерева (Santalum album) - 0.019 г; коріння сативари (Asparagus racemosus) - 1.425 г; плодів амла (свіжих) (Emblica officinalis) - 235.25 г; кори далкхини (Cinnamomum zeylanicum) 0.294 г [9].

Математична обробка результатів дослідження проводилась 3 використанням статистичних программ "Statgraf", "Matstat", Microsoft Excel для Windows, а при вивченні значущості розбіжностей статистичних відбірок використовувались пара- та непараметричні критерії [6].

\section{РЕЗУЛЬТАТИ ТА ЇХ ОБГОВОРЕННЯ}

Розподілення дітей - вихованців дитячих будинків, які брали участь у цьому дослідженні, за показником віку подане у таблиці 1. 
Характеристика обстежених дітей 3 дитячих будинків за віком

\begin{tabular}{l|c|c|c|c}
\hline \multirow{2}{*}{ Всього } & $3-7$ років & $7-10$ років & $10-14$ років & старші за 14 років \\
\hline \multirow{2}{*}{$\mathrm{N}=114$} & $\mathrm{n}=32$ & $\mathrm{n}=18$ & $\mathrm{n}=26$ & $\mathrm{n}=38$ \\
& $28 \%$ & $15,7 \%$ & $23 \%$ & $33,3 \%$ \\
Середній вік у групі (роки) & $4,9 \pm 0,2$ & $\mathbf{8 , 1} \pm 0,35$ & $13,1 \pm 0,2$ & $15,8 \pm 0,2$ \\
\hline
\end{tabular}

Аналіз інтенсивності гострої респіраторної захворюваності у 114 дітей - вихованців дитячих будинків віком від 3 до 17 років показав, що до групи часто хворіючих на ГРВІ (ЧХД) за критеріями В.Ю. Альбицького [3] належала 101 дитина (основна група спостереження), 13 дітей аналогічного віку характеризувались як епізодично хворіючі (ЕХД) - група порівняння.

За статевою ознакою серед ЧХД осіб чоловічої статі зареєстровано у $51 \%$ спостережень $(\mathrm{n}=51)$, жіночої статі - у 49\% (n=50), серед ЕХД 5 дівчаток $(38,5 \%)$ та 8 хлопчиків $(61,5 \%)$.

У структурі гострих респіраторних захворювань у ЧХД 3 дитячих будинків за частотою реєстрації на першому місці зареєстровані ГРВІ, на другому місці - гострий бронхіт та гострий трахеїт, в анамнезі 20\% обстежених дітей мали зафіксований гострий ларинготрахеїт, гостра пневмонія реєструвалась на четвертому місці, а рецидивуючий бронхіт зареєстрований у 14,9\% цих спостережень.

Аналіз анамнестичних даних у ЧХД віком від 3 до 17 років з організованих колективів показав наявність від чотирьох до шести епізодів ГРВІ протягом попереднього року життя $(5,3 \pm 0,5$ у середньому) 3 середньою тривалістю одного епізоду ГРВІ 5,8土0,6 дня (мінімальна тривалість 4 дні, максимальна - 8 днів).

Хронічні вогнища інфекцій верхніх дихальних шляхів серед дітей основної групи спостереження були зареєстровані у 80 обстежених дітей $(79,2 \%)$, у структурі яких компенсований хронічний тонзиліт спостерігався у 69\% випадків, аденоїдні вегетації у 19,8\% спостережень, прояви карієсу мала кожна третя дитина.

Флора слизових зіву та носу за якісними характеристиками визначалась типуванням 16 видів мікроорганізмів. За результатами мікробіологічного обстеження слизових зіву та носу діти основної групи та групи контролю мали порівняні характеристики стану мікробної колонізації слизових зіву та носу, з дещо вищим коефіцієнтом бактеріальної присутності у дітей, які часто хворіють, за рахунок різноманіття видів нормальної мікрофлори слизових та представництва умовно-патогенної флори.

За результатами мікробіологічного обстеження слизових зіву у вихованців 3 дитячих будинків віком від 3 до 17 років у стані клінічного благополуччя на першому місті реєструвалось зростання стрептококів групи Viridians $(53,3 \%)$, на другому місці - Staph. aureus (46,7\%) та Neisseriae Spp. (43,4\%). Умовно-патогенні стрептококи (Strep. haemolyticus i Strep. Pyogenes) зі слизових зіву висівались у 26,6\% випадків. Епізодично реєструвалося зростання Staph. epidermidis (5\%), дифтероїдів (Cor. pseudodiphtheribicum $i$ Cor. xerosis - 5\% і 3,3\% відповідно), грибів p. Candida (5\%), Pseudomonas aeruginosae (1,6\%), бактерій роду Enterobacter $(1,6 \%)$ та E. coli $(1,6 \%)$.

Аналіз результатів висівів зі слизових носу в дітей 3 дитячих будинків показав, що в обсіменінні такого рівня провідна роль належала грампозитивним кокам - Staph. epidermidis $(56,7 \%)$ i Staph. aureus (22,2\%). Дифтероїди (Cor. xerosis та Cor. Pseudodiphtheribicum) висівались у $20 \%$ випадків. Решта мікроорганізмів зустрічалися рідше - Strep. viridans (13,3\%), Haemophilus influenza (6,7\%), Neisseriae Spp. (3,3\%), Strep. haemolyticus $(1,6 \%)$ i Strep. pyogenes $(1,6 \%)$.

Таким чином, у дітей 3 дитячих будинків віком від 3 до 17 років на слизових верхніх дихальних шляхів домінує нормальна флора, але в кожної п'ятої дитини зареєстровані високі рівні колонізації нормальної мікрофлори зіву (Strep. Viridans до $10^{15}$ та Neisseriae Spp. до $10^{7}$ ) та носу (Strep. viridans та Cor. xerosis до $10^{7}$ ), що у поєднанні з реєстрацією високого титру росту умовно патогенної флори (в 75\% випадків титри зростання Staph. aureus вищі ніж $10^{4}$ КУО/мл) дозволяє констатувати наявність дисбіозу слизових верхніх дихальних шляхів у 83,3\% даних спостережень [8].

У ЧХД віком від 3 до 17 років 3 дитячих будинків у періоді клінічного здоров'я в ротоглотковому секреті (рис. 1.) реєструвався вірогідно низький вміст протимікробних білків 
$\alpha$-дефензинів (HNP 1-3) та SIgA порівняно 3 групою ЕХД $(\mathrm{p} \leq 0,05)$. Вміст лактоферрину в ротоглотковому секреті у ЧХД достовірно не відрізнявся від показників у ЕХД.

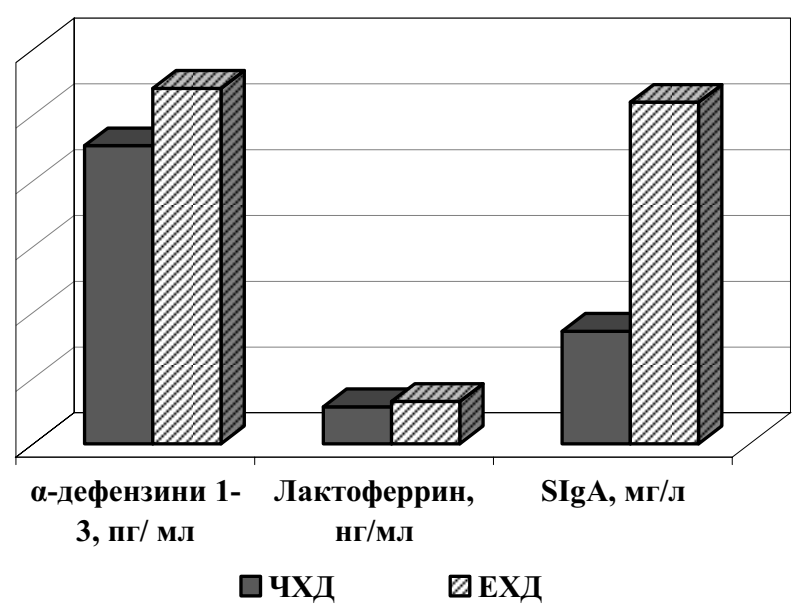

Рис. 1. Порівняльна характеристика показників системи місцевого імунітету у часто та епізодично хворіючих дітей - вихованців дитячих будинків у періоді клінічного благополуччя

Проведення кореляційного аналізу результатів дослідження стану місцевого імунітету у вихованців дитячих будинків віком від 3 до 17 років у періоді клінічного благополуччя підтвер- дило наявність взаємозв'язків між станом колонізації слизових ВДЩ та вмістом протимікробних білків у ротоглотковому секреті (рис. 2).

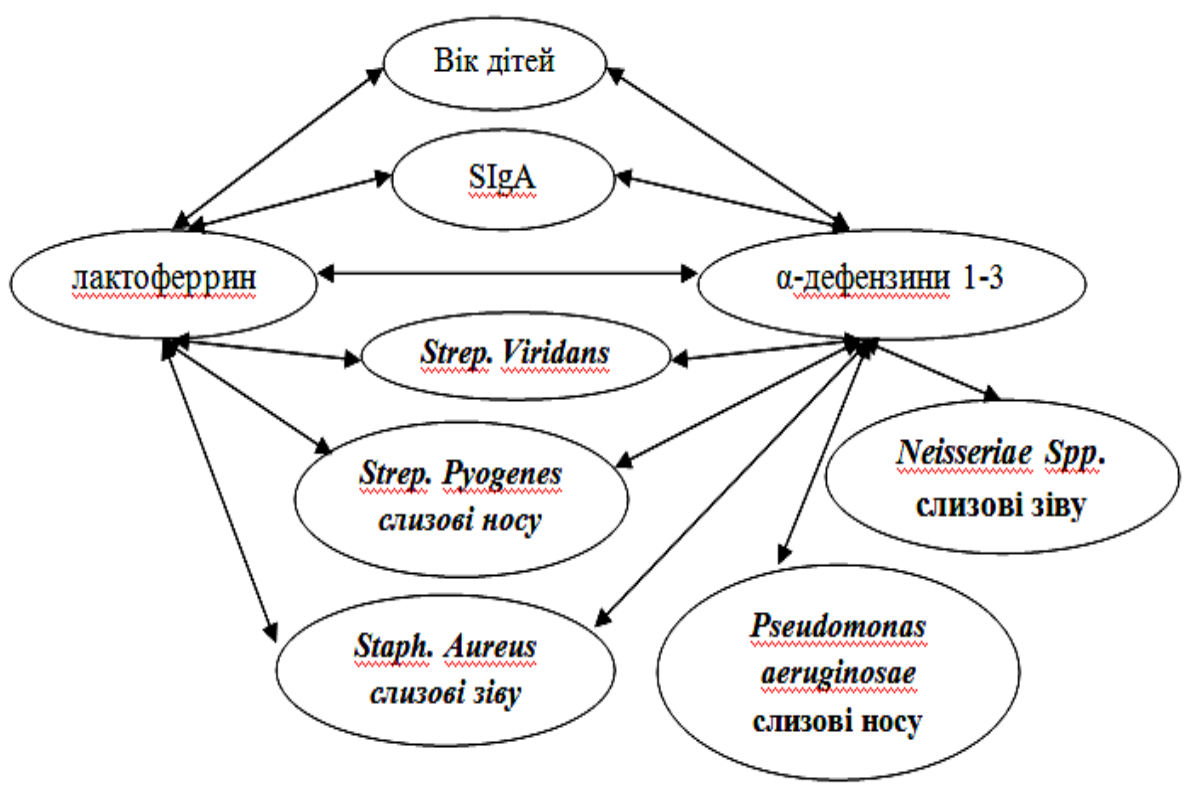

Рис. 2. Основні кореляційні взаємозв'язки між показниками системи місцевого імунітету та характеристиками мікробіоценозу слизових зіву та носу ЧХД з дитячих будинків у періоді клінічного благополуччя

Всім ЧХД, які були під нашим наглядом, 3 урахуванням отриманих результатів, перед початком епідемічного сезону було призначено профілактичний курс багатокомпонентним рослинним препаратом протягом 4 тижнів [9].
Перенесення препарату у всіх дітей було добрим, лише у однієї дитини (0,9\% випадків) на 5 добу прийому було зареєстровано блювання, що зумовило її виключення 3 цього дослідження. В інших дітей побічних реакцій, зокрема алергічних, 
не відзначалось, хоча кожна п’ята дитина відзначала незначну гіркоту в роті (за рахунок складових перцю).

Клінічна ефективність профілактичного курсу рослинним препаратом 3 урахуванням даних катамнестичного спостереження за інтенсивністю захворюваності за дітьми 3 дитячих будинків впродовж року становила $88 \%$ за рахунок зменшення кратності ГРВI в 1,3 разу та зменшення тривалості гострого респіраторного епізоду на 2,2 дня у середньому.

Контрольне дослідження стану біоценозу слизових ВДШ у ЧХД 3 дитячих будинків після профілактичного курсу терапії комплексним рослинним препаратом показало відсутність на слизових зіву й носу таких патогенів, як Strep. pyogenes, Haemophilus influenza, Enterobacter та E. coli, а титри росту Staph. aureus та Strep. haemolyticus знизились майже вдвічі, при цьому якісний склад нормальної мікрофлори як зіву, так і носу не зазнавав змін, але кількісні показники колоній-утворюючої здатності мікроорганізмів ставали приблизно однаковими та становили у середньому не менше ніж $10^{3} \mathrm{KУО} / \mathrm{Mл}$ для таких бактерій, як Strep. Viridans, Neisseriae Spp. та Cor. Xerosis, що дозволяє стверджувати про формування стану еубіозу після терапії.

Зміни показників системи місцевого імунітету після закінчення профілактичного курсу багатокомпонентним рослинним препаратом та їх порівняння з даними у ЕХД подані в таблиці 2.

Таблиия 2

Динаміка показників системи місцевого імунітету у ЧХД з дитячих будинків до та після

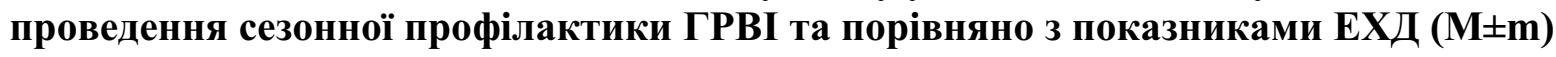

\begin{tabular}{|c|c|c|c|c|}
\hline Показники & $\begin{array}{c}\text { Одиниці } \\
\text { вимірювання }\end{array}$ & ЧХД до лікування & ЧХД після лікування & ЕХД \\
\hline а-дефензини 1-3 & пг/ мл & $2266,9 \pm 93,4$ & $1805,6 \pm 65,9^{0}$ & $2702,46 \pm 91,9$ \\
\hline Лактоферрин & нг/мЛ & $28,2 \pm 2,5$ & $40,4 \pm 2,1^{*}$ & $32,1 \pm 4,4$ \\
\hline $\operatorname{SIgA}$ & мг/л & $85,6 \pm 9,7^{0}$ & $137,95 \pm 12,5^{* 0}$ & $296 \pm 36$ \\
\hline
\end{tabular}

Пр и м і т и : знаком * - помічені дані, що вірогідно відрізняються на фоні терапії (p $\leq 0,05)$, знаком ${ }^{0}$ - помічені дані, що вірогідно відрізняються від показників ЕХД ( $\leq \leq 0,05)$.

У ЧХД віком від 3 до 17 років $з$ дитячих будинків реєструється вірогідне підвищення концентрації секреторного імуноглобуліну А та лактоферрину в ротоглотковому секреті майже вдвічі порівняно з вихідними даними до початку терапії $(\mathrm{p} \leq 0,05)$ та тенденція до зниження ( $\mathrm{p} \geq 0,05)$ рівнів $\alpha$-дефензинів 1-3 після терапії (табл. 2).

Порівняння імунологічних результатів у ЧХД після терапії з аналогічними у ЕХД 3 дитячих будинків показало, що вміст протимікробного білка лактоферрину у ЧХД відновлювався до рівня у ЕХД, а концентрація SIgA, хоча й вірогідно збільшилася, але не набувала рівня ЕХД з організованих колективів (табл. 2).

\section{ВИСНОВКИ}

1. У більшості дітей 3 дитячих будинків віком від 3 до 17 років (83,3\% даних спостережень) у періоді клінічного благополуччя мають місце прояви дисбіозу слизових зіву та носу.

2. У часто хворіючих вихованців 3 дитячих будинків віком від 3 до 17 років зареєстровано зниження вмісту протимікробних білків $\alpha$-дефензинів 1-3 та SIgA у ротоглотковому секреті порівняно з показниками епізодично хворіючих дітей, що свідчить про дисбаланс місцевого імунітету слизових верхніх дихальних шляхів у періоді клінічного благополуччя.

3. Ефективність сезонної профілактики ГРВІ у часто хворіючих дітей 3 дитячих будинків віком від 3 до 17 років в умовах організованих колективів з використанням багатокомпонентного рослинного препарату становила $88 \%$ та була зумовлена імунотропним впливом складових препарату за рахунок підвищення концентрації SIgA та вмісту лактоферрину у ротоглотковому секреті.

\section{СПИСОК ЛІТЕРАТУРИ}

1. Абатуров А.Е. Антимикробные энзимы системы неспецифической защиты респираторного тракта / А.Е. Абатуров // Здоровье ребенка. - 2009 - №3(18) C. $122-125$.
2. Абатуров А.Е. Катионные антимикробные пептиды системы неспецифической защиты респираторного тракта: дефензины и кателицидины. Дефензины - молекулы переживающие ренессанс. 
Ч. 4 / А.Е. Абатуров // Здоровье ребенка. - 2012. - № 2. C. 154-161.

3. Альбицкий В.Ю. Часто болеющие дети. Клинико-социальные аспекты. Пути оздоровления / В.Ю. Альбицкий, А.А. Баранов. - Саратов: Изд-во Саратов. ун-та, 1986. - 184 с.

4. Аналіз та тенденції захворюваності дитячого населення України / Р.О. Моісеєнко, Я.І. Соколовська, Т.К. Кульчицька, Т.М. Бухановська // Соврем. педиатрия - 2010 - №3(31) - С. 13-17.

5. Андрианова Е.Н. Дисбиоз верхнего отдела респираторного тракта и изменение функционального состояния органов дыхания у часто болеющих детей / Е.Н. Андрианова, Н.Ю. Снегирева, А.И.Рывкин // Педиатрия. - 2009. - Т.87, №2 - С. 34 -39.

6. Герасимов А.Н. Медицинская статистика / А.Н. Герасимов. - М: Мед. информ. агентство, 2007. $475 \mathrm{c}$.

7. Демографічна політика та соціальне сирітство: аналіз та прогноз сучасної ситуації / Т.А. Сіротченко,
О.М. Гєтта, А.О. Бобришева, О.А. Топоркова // Здоровье ребенка. - 2011. - №3 (30) - С. 42- 46.

8. Извин А.И. Микробный пейзаж слизистой оболочки верхних дыхательных путей в норме и патологи / А.И. Извин, Л.В. Катаева // Вестник отоларингологи. - 2009. - № 2. - С. 64-68.

9. Справочник «Компендиум 2012 - лекарственные препараты» / под ред. В.Н. Коваленко ISBN: 978-966-2066-46-3 [електронний ресурс http://compendium.com.ua]

10. Можливості корекції адаптивного та вродженого мукозального імунітету у дітей з повторними респіраторними захворюваннями / С.А. Якимович, Л.І. Чернишова, А.В. Чернишов [та ін.] // Соврем. педиатрия. - 2010. - № 4 (32). - С. 234.

11. Human defensins and LL-37 in mucosal immunity // M. Doss, M.R.White, T. Tecle, K.L. Hartshorn // J. Leukoc. Biol. - 2010. - Vol.87 - P. 79 - 92.

12. Kelly D. Commensal gut bacteria: mechanisms of immune modulation / D. Kelly, S. Conway, R. Aminov // Trends. Immunol. - 2005. - Vol. 26, N 6. - P. 326-333.

\section{REFERENCES}

1. Abaturov AE. Antimikrobnye enzimy sistemy nespetsificheskoy zashchity respiratornogo trakta. Zdorov'e rebenka. 2009;3(18):122-5.

2. Abaturov AE. Kationnye antimikrobnye peptidy sistemy nespetsificheskoy zashchity respiratornogo trakta: defenziny i katelitsidiny. Defenziny - molekuly perezhivayushchie renessans (Ch. 4). Zdorov'e rebenka. 2012;2(37):154-61.

3. Al'bitskiy VYu, Baranov AA. Chasto boleyushchie deti. Kliniko-sotsial'nye aspekty. Puti ozdorovleniya. Iz-vo Saratovskogo universiteta. 1986:184.

4. Moiseєnko RO, Sokolovs'ka YaI, Kul'chits'ka TK, Bukhanovs'ka TM. Analiz ta tendentsiï zakhvoryuvanosti dityachogo naselennya Ukraïni. Sovremennaya pediatriya. 2010;3(31):13-7.

5. Andrianova EN, Snegireva NYu, Ryvkin AI. Disbioz verkhnego otdela respiratornogo trakta i izmenenie funktsional'nogo sostoyaniya organov dykhaniya $u$ chasto boleyushchikh detey. Pediatriya. 2009;87(2):34-9.

6. Gerasimov AN. Meditsinskaya statistika. M: Med. informatsionnoe agentstvo. 2007:475.
7. Sirotchenko TA, Getta OM, Bobrisheva AO, Toporkova OA. Demografichna politika ta sotsial'ne siritstvo: analiz ta prognoz suchasnoï situatsiï. Zdorov'e rebenka. 2011;3(30):42- 6.

8. Izvin AI, Kataeva LV. Mikrobnyy peyzazh slizistoy obolochki verkhnikh dykhatel'nykh putey v norme i patologi.Vestnik otolaringologi. 2009;2:64-8.

9. Spravochnik «Kompendium 2012 - lekarstvennye preparaty» / Pod redaktsiey VN. Kovalenko - ISBN: 978-966-2066-46-3 [elektronniy resurs http://compendium.com.ua]

10. Yakimovich SA, Chernishova LI, Chernishov AV, Dons'koy BV, Galazyuk LV. Mozhlivosti korektsiï adaptivnogo ta vrodzhenogo mukozal'nogo imunitetu $\mathrm{u}$ ditey $\mathrm{z}$ povtornimi respiratornimi zakhvoryuvannyami. Sovremennaya pediatriya. 2010;4(32):234.

11. Doss M, White MR, Tecle T, Hartshorn KL. Human defensins and LL-37 in mucosal immunity. J. Leukoc. Biol. 2010;87:79-92.

12. Kelly D, Conway S, Aminov R. Commensal gut bacteria: mechanisms of immune modulation. Trends Immunol. 2005;26(6):326-33. 